\title{
Reforms, Entry and Productivity: Some Evidence from the Indian Manufacturing Sector*
}

\author{
Sumon Kumar Bhaumik ${ }^{* *}$ \\ Centre for Economic Development and Institutions \\ Brunel University \\ Shubhashis Gangopadhyay \\ India Development Foundation \\ Shagun Krishnan \\ India Development Foundation
}

\begin{abstract}
:
Traditional research in the context of product market entry has explored the strategic reactions of incumbent firms when threatened by the possibility of entry, and have identified industry-specific factors that affect entry rates. However, following De Soto (1989), there has been increasing emphasis on regulatory and institutional factors governing entry rates, especially in the context of developing countries. Using 3-digit industry level data from India, for the 1984-97 period, we examine the phenomenon of entry in the Indian context. Our empirical results suggest that during the 1980s industry level factors largely explained variations in entry rates, but that, following the economic federalism brought about by the post-1991 reforms, variations entry rates during the 1990s were explained largely by state level institutional and legacy factors. However, we do not find evidence of impact of net entry rates on industry-level productivity growth.
\end{abstract}

Keywords: Entry, Productivity, Institutions, Regulations, India, Reforms

JEL classification: L11, L52, L64, L67, O14, O17

October 27, 2008

\footnotetext{
* The authors would like to thank Suma Athreya, Ralitza Dimova, Saul Estrin, Igor Filatotchev, Stephen Gelb, John Hunter, Leora Klapper, Kalpana Kochhar, Tomasz Mickiewicz, Mario Nuti, Murali Patibandla, Virginie Perotin, Klara Sabirianova, M.R. Saluja, seminar participants at Aarhus School of Business, Binghamton University, Brunel University, Keele University, London Business School, Queen's University Belfast and the School of Slavonic and East European Studies of University College London, and an anonymous referee for their advice about the conceptual issues, data, and econometric methodology. They remain responsible for all remaining errors. The research was facilitated by a grant from the Department for International Development of the UK government.

${ }^{* *}$ Corresponding author. Address: Brunel University, Economics and Finance, School of Social Sciences, Marie Jahoda, Uxbridge UB8 3PH, United Kingdom. Phone: +44 1895 267247. Fax: +44 1895 269786. Email: Sumon.Bhaumik@ brunel.ac.uk.
} 


\section{Reforms, Entry and Productivity: Some Evidence from the Indian Manufacturing Sector}

\section{Introduction}

It is now fairly stylized that competition is a desirable characteristic of a market because it encourages innovation and leads to improvement in the both the production and $\mathrm{x}$ - efficiencies of an average firm in an industry (Geroski, 1995; Stennek, 2000). Nickell (1996), for example, argued that competition does indeed enhance firm performance, and Pilat (1996) concluded that there is a positive relationship between productivity in OECD countries and the extent to which their manufacturing firms face domestic and international competition. The importance of competition in augmenting efficiency or productivity is particularly important on account of the complex relationship between ownership and firm performance which is influenced by different types of agency problems.

It is generally accepted that the degree of competition in a market is directly proportional to its contestability, i.e., on the ease with which new firms can enter the market to compete with the incumbent firms (Jovanovic and Lach, 1989; Baldwin and Gorecki, 1991; Liu, 1993; Aw, Chen and Roberts, 2001). Not surprisingly, therefore, the process of entry and exit and the barriers thereof have attracted a fair amount of attention. A significant proportion of the literature on product market entry has focussed on industry characteristics like profitability and sunk cost requirements, and strategic interaction between potential entrants and incumbent firms who aim to deter entry. ${ }^{1}$ However, as highlighted by Geroski (1995), it has proved difficult to explain entry rates using conventional measures of profitability (of incumbent firms) and entry barriers. This has led to rethinking about the drivers of entry, and the path-breaking study by De Soto (1989) brought to the fore the fact that institutional factors might explain net entry rates much better than industry-level and strategic factors, especially in the context of developing economies. This has triggered a literature that aims to identify the nature of impact of institutional factors on entry rates.

In one of the first studies of its kind, Djankov et al. (2002) used data from 85 countries to conclude that entry costs are higher in poorer countries and in countries that entry is more heavily regulated in countries that do not have democratic governments. Perotti and Volpin (2004) analyse data from 33 industries spread across 38 countries and argue that if wealth distribution is unequal then incumbent firms are able to prevent entry by way of lobbying the politicians for entry-deterrent regulations. Finally, Klapper, Laeven and Rajan (2006), who use a

\footnotetext{
${ }^{1}$ See Bain (1956), Stigler (1968), Schmalensee (1978), Dixit (1980), Eaton and Lipsey (1980), Aghion and Bolton (1987), Evans and Jovanovic (1989), Hart and Tirole (1990), Bolton and Whinston (1991, 1993), Geroski and Murfin (1991), Rasmusen, Ramseyer and Wiley (1991), Seabright (1996), and Tybout (1997).
} 
comprehensive database of European firms, find that entry rate is affected by regulations, capital market imperfections and property rights.

One of the well known shortcomings of cross-country studies is that they rely on the use of broad-brush controls like "democracy" or "legal origin" or "protection of property rights" that are themselves fairly heterogeneous. The Klapper et al. (2006) methodology goes a long way in addressing some of the problems associated with cross-country studies, but still does not account for divergence between de jure and de facto implementation of regulations that may be quite significant in developing countries. One possible way to address this lacuna in the literature is to analyse entry rates at the sub-national level where the letter of the law is necessarily the same everywhere but where implementation might vary widely across regions. In this paper, we adopt this approach to examine the determinants of entry rates.

We use data from India, a large and fast growing developing country that has witnessed reforms since the early 1980s (Virmani, 2004; Rodrik and Subramanian, 2004) to examine the determinants of entry rates. Rodrik and Subramanian (2004) go on to suggest that the decade of the 1980s was characterised by a pro-incumbent business policy while the 1990s was a more pro-entrant policy (for details, see Bhaumik, Gangopadhyay and Krishnan, 2008). This allows us to compare product market entry in the 1980s with that in the 1990s. Further, while the country has a unified legal-regulatory structure, its federal nature and specific characteristics of post-1991 liberalisation has resulted in significant variation in institutions or business environments across the states that comprise the union. For example, there is prima facie evidence to suggest that, in post-1991 India, there was inter-state variation in the degree of accountability of the state governments (Besley and Burgess, 2004). These variations within the political and legal union, which we call economic federalism, allows us to move away from discussions about opaque measures of institutions like a "democracy" dummy (or index) and, instead, use in our analysis more transparent measures of local institutions that might affect entry. They also allow us to hypothesise, along the lines of Aghion et al. (2005) and Kochhar et al. (2006), that institutions played a greater role in influencing entry rates in the 1990s than in the 1980s.

Our results suggest that during the 1980s, entry was influenced mostly by industry-level factors like growth. By contrast, in the 1990s, state level factors like availability of skilled labor and accountability of the state government to the electorate emerged as the most important determinants of net entry rates. In addition, variations in entry across industries and states in the post-1991 period were largely explained by unobserved state-level factors, thereby highlighting the importance of institutional factors and governance in an era of economic federalism. Finally, our analysis suggests that for the periods of analysis there is no evidence of entry-driven productivity growth, even though productivity growth may have affected net entry rates with a lag, through its impact on the growth of value added. 
The rest of the paper is organised as follows: In Section 2, we develop the empirical specification that is subsequently used to identify the determinants of entry rates. The data and the measurement of the variables used in the entry regression are discussed in Section 3. Section 4 reports the regression results. In Section 5, we briefly examine the relationship between entry and productivity. Finally, Section 6 concludes.

\section{Determinants of entry}

As mentioned above, in this paper, we aim to identify the determinants of entry, and the impact of entry on productivity. To the extent that we are interested in "entry" as a manifested outcome of liberal economic policies, one that subsequently has an impact on productivity, its connotation may depend significantly on the context in which it is discussed. For a mature market economy where the observed output levels, input-output mix etc of the incumbent firms are an outcome of their optimization exercises, the status quo can change, leading to greater competition, only if new firms enter, or credibly threaten to enter. In a controlled economy, however, a variety of factors prevent incumbent firms themselves to operate an at output level, or with input-output mixes that are optimal. ${ }^{2}$ In such a context, adoption of liberal economic policies may lead to greater competition by way of changes in the output levels and input-output mix of the incumbent firms themselves, even if new firms per se do not enter the product market. In other words, "entry" in these contexts can be viewed as a phenomenon involving not only entry of a new firm with one or more new production units, but also the process of expansion of incumbent firms by way of establishment of additional production units. ${ }^{3}$ Further, in the context of a large country with significant inter-regional differences, cross-regional "entry" rates may also reflect relocation of industrial units from regions of mis-governance to regions that are better governed, i.e., "entry" as a phenomenon may have a spatial dimension.

In order to capture these two dimensions of the entry dynamics witnessed in India in the 1980s and the 1990s, we think of entry rate in India being characterized by indices $i$ and $j$ where $i$ refers to the industrial sectors and $j$ refers to the states. Assuming that there are $m$ industry level factors $(X ; i=1,2, \ldots, m)$ and $n$ state level factors $(Z ; j=1,2, \ldots, n)$ that affect entry rates $(Y)$, we, therefore, propose to estimate the following model:

$$
Y_{i j}=\alpha+\sum_{i=m} \beta_{i} X_{i j}+\sum_{j=n} \gamma_{j} Z_{i j}+e_{i j}
$$

\footnotetext{
${ }^{2}$ For example, prior to the 1990s, the Monopoly and Restrictive Trade Practices (MRTP) Act in India prevented incumbent firms from increasing productive capacity beyond a certain size, even if the long run optimal level of output of these firms lay beyond this threshold size.

${ }^{3}$ By the same token, "exit" would comprise not only closure of entire firms, but also of some productive units of some of the firms.
} 
This aspect of our methodology is similar to the approach of Klapper et al. (2006); each of their observations is indexed by industry $j$ and country $k$. However, as we shall explain later in the paper, our empirical strategy differs from that of Klapper et al. in an important way.

Following Tybout (1997), entry rates are influenced by the following industry characteristics:

Growth of the industry: Not surprisingly, entry is likely to be higher for fast growing industries than for their stagnant counterparts. Indeed, net entry might actually be negative for industries that are either not growing or are experiencing negative growth.

Technology: If an industry has an old technology, the advantage lies with incumbent firms because the currency of competition in such industries is not innovation but factors like economies of scale. However, if the competitive edge in an industry is incumbent on access to technology and associated innovation, it is possible for new firms to leapfrog incumbent firms in terms of productivity and efficiency, thereby making the industry more open to new entry.

Industry concentration: If an industry is concentrated, such that a handful of incumbent firms account for a disproportionately large share of the output, these firms are in a position to earn supernormal profits, and hence have a lot to lose if entry makes the market more competitive. Incumbents in concentrated markets, therefore, are likely to lobby the governments and use other strategic measures to prevent entry as much as possible. Chari and Gupta (2005), for example, have found evidence in the Indian context that suggest that regulations that raise entry barriers for foreign firms are more likely to be found for industries that are highly concentrated.

Number of incumbent firms: Even if a market is not concentrated, such that an individual incumbent firm does not have the capability to deter entry to a significant extent, the total number of incumbent firms is likely to influence entry rates in developing countries where resources are relatively scarce and where existing resources may be contractually tied to the incumbent firms. Indeed, some resources like able managerial labor may be organizationally embedded in incumbent firms in the form of the owner-managers of these firms. Hence, in developing country contexts, entry rate for an industry is likely to be negatively related with the number of incumbent firms in the industry.

It is more difficult to decide on the state level factors that may affect entry rates, largely because the economic factors are usually highly correlated with each other, as also with political or institutional characterizations of the states. However, on the basis of the "institutional" literature cited earlier in this paper, we account for the following state level factors:

Economic growth: It is stylized that GDP growth rate is strongly correlated with firm entry and foreign direct investment at the national or country level. By the same token, growth of state domestic product, the state level equivalent of the GDP, should have an impact of entry, with higher growth being associated with higher entry rates. 
Nature of democracy: Cross country studies (e.g., Djankov et al., 2002) have suggested that factors like democracy can play a role in determining entry rates. While the legal and constitutional aspects of democracy would be the same across India, the federal nature of the democracy implies that the nature of democracy, i.e., the relationship between the government and other stakeholders at the state level may vary considerably across the country. In particular, regional political parties, whose collective political fortune has been on the rise since the late 1980s, and who have come to dominate the political landscape in India since the 1990s, may behave very differently from national political parties whose political fortunes are more diversified across states than those of the former.

Further, precisely because democracy reduces the ability of special interest groups to influence the economic agenda of a government, and given the fact that in India the livelihood of nearly two-thirds of the people continue to be associated with agricultural activities, with formal sector employment accounting for less than 5 per cent of the labor force, it is not obvious as to whether democracy at the state level in India would necessarily favor entry into and expansion of the industrial sector. In other words, the impact of state level democracy on entry in India is an open empirical question.

Labor: Industrial development in India responded to the policy emphasis on tertiary education and the development of a capital goods sector, employment protection in the formal sector, and financial repression in the pre-1991 era by channelling the manufacturing sector into skill-intensive industries (see, e.g., Bhagwati and Desai, 1970; Joshi and Little, 1994). This trend has continued beyond 1991, the additional twist being the rise and the growth of the skillintensive industries (Kochhar et al., 2006). Hence, at least in the post-1991 period, spatial differences in entry rates should, in principle, find an explanation in state level differences in the availability of skilled labor.

Following Botero et al. (2004) and Besley and Burgess (2004), entry rates would also depend on factors like labor regulations. Once again, while labor laws are largely uniform across India, there is considerable variation across states in the bargaining power of labor(ers) vis-à-vis the industrial units and their management. In states like Kerala and West Bengal, in which the Indian communist parties are on a strong footing, a significant proportion of formal sector laborers are unionized and often have the tacit support of the state administration when they bargain for wages and benefits with the aforementioned management. The currency for bargaining is usually industrial action. The degree of unionization of laborers is much less in some of the other states, and some state governments are viewed as being pro-industry, as opposed to being pro-labor. Ceteris paribus, we can expect lower entry rates in states where laborers have relatively greater bargaining power, with or without explicit political support of the state governments. 
Legacy: The economic geography literature has long held that industries can enjoy significant agglomeration economies if they locate production units in geographical locations (e.g., Hoover, 1948). One implication of the presence of such economies is that certain locations within large countries attract much of the manufacturing production units, while other regions remain largely agricultural (Krugman, 1991). Hence, in the Indian context, a priori states like Gujarat and Maharashtra, which have had a strong manufacturing core can be expected to witness more entry relative to other states.

It is easy to see how our empirical strategy deviates from that of Tybout (1997) who analysed entry rates using only industry characteristics. But we also deviate Klapper et al.'s (2006) methodology which addresses a question of the following type: if Gujarat is the state where the business environment (or institutions) is most favorable for entry among Indian states, what are the factors that reduce entry rates in other Indian states vis-à-vis Gujarat? We, on the other hand, seek to examine the impact and relative importance of industry-level and state-level factors on entry rates. In addition, we feel that it is reasonable to argue that variables that capture the nature of political institutions and resource allocation at the state level are likely to affect long term entry as opposed to contemporaneous entry rates.

We, therefore, adopt the following strategy: We use as our dependent variable the change in the number of plants belonging to industry $i$ in state $j$ over the 1984-91 and 1992-97 periods, those roughly corresponding to the two reforms periods mentioned in Rodrik and Subramanian (2004). This is consistent with the approach of Perotti and Volpin (2004) whose dependent variable was entry during the 1983-92 period. We then use as our explanatory variables the average values for the aforementioned industry-level and state-level determinants of entry rates for each of these periods. ${ }^{4}$ In addition, we control for the initial number of plants belonging to each industry in each state. In other words, if $N_{i j}$ is the number of plants belonging to industry $i$ in state $j$, our (modified) regression model is given by the following:

$$
\Delta N_{i j}=\alpha+\sum_{i=m} \beta_{i} X_{i j}+\sum_{j=n} \gamma_{j} Z_{i j}+\lambda N_{0, i j}+e_{i j}
$$

when $N_{0, i j}$ is the initial number of firms belonging to industry $i$ in state $j$. The vector $X$ includes the following industry level factors: a proxy of industry level growth, the nature of technology used for production, the degree of concentration of the industry, the initial number of production units, and a proxy of the minimum efficient scale that, in turn, determines the extent of a new

\footnotetext{
${ }^{4}$ Note that the use of averaging values across time to capture long term relationships between variables is not uncommon, especially in the growth and financial economic literature (e.g., Barro, 1991; Chirinko and Elston, 2006). As pointed out by Pesaran and Smith (1995), the resultant estimates are consistent if the time span over which the averaging is done is long. In our case, the averaging is being done over six to eight years. By comparison, an average postWorld War II business cycle in the United States of America has lasted about five years peakto-peak, including about 45 months of expansion and about 11 months of recession.
} 
entrant's required financial commitment. On the other hand, the vector $Z$ includes the following state level factors: economic growth, a proxy of the nature of democracy at the state level, a proxy of the quality of available labor, a proxy of the bargaining power of the labor force, and a measure of the initial degree of industrialization at the state level. Such 3-digit industry level analysis of entry in the Indian context can also be found in Aghion et al. (2005).

\section{Data and variables}

We restrict our analysis to the $1984-97$ period. The years prior to 1984 were marked by war (1971), oil price shock, political crisis (1974-80), industrial strife (1982-83), insurgency in northern India (1980-84), and the assassination of Indira Gandhi (1984). Post-1997 data, on the other hand, is incompatible with the pre-1997 data because of several changes in the format in which the Annual Survey of Industries (ASI) collects plant-level information, the ASI archive being our main data source for entry rates. ${ }^{5}$ However, the 1984-97 period captures the entire time frame of the Rodrik and Subramanian (2004) analysis, and was largely stable politically. It, therefore, allows us to undertake a meaningful analysis of entry while, at the same time, contrasting the determinants of net entry in the pre- and post-1991 periods. Specifically, we contrast the determinants of net entry in the 1984-91 period with those in the 1992-97 period.

Further, our analysis is based on data from 15 states (out of the possible 32 during the period covered by the data presented here). ${ }^{6}$ There are many reasons for restricting ourselves to these states. First, these states have existed for the entire period of the data without any change in their geographical area or administrative setup. For example, among the states that have been left out, there are many that have moved from being centrally administered to ones where they elect their own state-level governments. Second, around 95 percent of the Indian population resides in these states. Third, more than 90 percent of all factories are located in these 15 states. Indeed, in many of the states that are left out of our sample, industrialization is a very recent phenomenon and, therefore, the methodology for collecting data in these states is not the same as in the states we are studying. The data collection methodology for the 15 states included in our sample has remained largely the same throughout our period of analysis.

The measurement of the variables that are included in the specification highlighted by equation (2) is described below. Our dependent variable has been generated using state-level 3digit industry data from ASI and is as follows:

\footnotetext{
${ }^{5}$ The ASI data are widely used in the context of analysis of the Indian industrial sector. See Hasan, Mitra and Ramaswamy (2003), Besley and Burgess (2004), Aghion et al., 2005, Aghion, Burgess, Redding and Zilibotti (2008), and Lall and Chakravorty (2005).

${ }^{6}$ These states are as follows: Andhra Pradesh, Bihar, Delhi, Gujarat, Haryana, Karnataka, Kerala, Madhya Pradesh, Maharashtra, Orissa, Punjab, Rajasthan, Tamil Nadu, Uttar Pradesh and West Bengal.
} 
Net entry: For each 3-digit industry, the net entry for the 1984-91 period is defined as the number of plants in 1991 less the number of plants in $1984 .^{7}$ Net entry for the 1992-97 period is similarly defined. One problem with the ASI data is that it classifies industrial units into the "census" sector and the "sample" sector. While the factories employing 100 or more workers constitute the census sector, the remaining factories constitute the sample sector. Each year, ASI collects and reports data for all units in the census sector, but only one in three units in the sample sector. In other words, for any industry, the difference in the number of plants between years $t$ and $t+1$ does not directly provide a measure of net entry. Further, as we demonstrate in the Appendix, under reasonable assumptions, it yields a monotonic transformation of the true measure of net entry.

The industry-level variables that explain variations in net entry across industry and regions, and each of which have been obtained from ASI data, have been measured as follows:

Growth of the industry: We measure growth of each industry as the percentage change in the aggregate real (net) value added by all plants in the industry. Since net entry over a period of time would almost certainly be affected by industry-level growth of all the years in this time period, we use as the explanatory variable the average of the annual growth rates of real (net) value added for all the years within each of the two time periods.

Technology: An ideal way of measuring technology would be the vintage of the machinery and equipment used by the industrial units. However, such detailed data are not available. Following Tybout (1997), we, therefore, used the capital-labor ratio, defined as the (real) value of fixed capital divided by the number of workers, as a proxy for technology. The underlying logic is that technology is approximately measurable by the mix of capital and labour. ${ }^{8}$ As in the case of industry growth, we use for our analysis, the average of the capitallabor ratio, for each 3-digit industry, across each of the time periods.

Industry concentration: Industry concentration has been measured as the proportion of total sales coming from the 4 largest industrial units in each of the 3-digit industries. Since the largest units are in the census sector of the survey, each round reports the sales of these units. Hence, our data does not suffer from any informational bias. The problem once again is that the sales data corresponds to plants and not firms, and hence our measure is not a 4-firm concentration ratio in the conventional sense. But, on account of data limitations, we continue to use this measure of industry competitiveness.

\footnotetext{
${ }^{7}$ The use of plant level data for discussion of creative destruction is deemed acceptable (see Bartelsman, Haltiwanger and Scarpetta, 2004).

${ }^{8}$ Note that this measure of technology also encompasses a measure of the capital required by a new entrant, on average, to successfully enter the market. Hence, if the coefficient of this variable is significant, it would require a careful interpretation.
} 
Number of incumbent plants: For each 3-digit industry, use the number of industrial units in 1984 and 1992, respectively, as the initial values of the number of plants for the 198491 and 1992-97 periods.

The state-level variables were collected from various sources, and they are as follows:

Economic growth: The state GDP figures are taken from the archives of the Economic and Political Weekly (EPW) Research Foundation.

Nature of democracy: As we have discussed earlier in this paper, democracy refers to the accountability of a government to the electorate. In the Indian context, given the continuing widespread poverty, we feel that accountability is best measured by the fiscal allocation of a government to public goods that directly affect the welfare of the vast majority of the electorate (e.g., Pourgerami, 1988; Stasavage, 2005). We, therefore, choose a state government's per capita expenditure on health as the measure for its accountability to the people of that state. ${ }^{9}$ The data on state-level budgetary allocation and state-level population have also been obtained from the EPW Research Foundation.

In addition, for each of the 1984-91 and 1992-97 periods, we construct the proportion of years during which a regional party was in power. The data on election results required to construct this variable were obtained from the Election Commission of India.

Labor: The ideal measure for high-skilled labor is the proportion of labor force with tertiary and/or technical education. However, such detailed data are not available for the states, and construction of this data from Census information is costly. We, therefore, assume that there is a high correlation of the number and/or proportion of people in different educational/skill cohorts, such that a crude measure like the literacy rate would capture the level of skill of the population or labor force at the state level. The data on literacy rate were taken from various issues of Selected Educational Statistics of the Department of Secondary and Higher Education, Ministry of Human Resource Development.

Following Besley and Burgess (2004), we use as our measure of state-level labor policy the number of man-days lost on account of industrial action. This data were collected from various editions of the Indian Labour Year Handbook. We have normalized this data using the total number of employees in the manufacturing sector of each state. The data on the number of employees were obtained from ASI.

Legacy: As explained earlier, we have to control for the initial level of industrialization of a state. For each state, we do so by using the share of the manufacturing sector in the state

\footnotetext{
${ }^{9}$ We have verified that per capita expenditure on health and per capita income are not systematically correlated at the state level, neither across states for a given year, nor across years for a given state. Hence, our measure of democracy is not collinear with, nor a proxy for, the extent of prosperity of a state.
} 
GDP in 1984 and 1991, respectively, for the 1984-91 and 1992-97 periods. The break down for the GDP of each state was obtained from the EPW Research Foundation.

Governance: we use two measures of the quality of governance, one of which, namely, state-level human development indices, captures accountability, growth, human capital of the people, etc, in one unified measure, we use state-level human development indices. The data for this index were taken from various issues of Health Information of India published by the Central Bureau of Health Intelligence, Ministry of Health and Family Welfare. The alternative measure of governance used in our analysis is state-level technical and distribution (T\&D) losses that embody accountability of the government as well as the state of infrastructure. The data for T\&D loss were obtained from the International Monetary Fund.

While our analysis is restricted to the 1984-97 period, we report in Figures 1 and 2 trends in net entry rates for the 1980-97 period. In the first 5 years of the 1980s, the average net entry rate was 0.55 , and in the next 5 years it was 2.29 , giving us an average rate of 1.42 for the decade. This low entry rate was largely influenced by a single political event, which is also an important reason for starting our analysis from $1984 .{ }^{10}$ In the 1990s, the first half witnessed a higher net entry rate (2.68). From the summary statistics, therefore, there is not much that distinguishes second half of the 1980s from the first half of the 1990s. The statistics merely reflect the fact that the business/policy environment was more conducive for entry in the second half of the eighties than in the first half, and this can largely be explained by the industrial action and the political events highlighted above.

INSERT Figures 1 and 2 about here.

However, this aggregate data does not reveal the role of state governments and institutions (i.e., economic federalism) in influencing the variation of net entry rates across the states. To recapitulate, prior to the nineties, the focus of the centrally controlled industrial policy was on reducing regional disparities. The liberalization policies of the nineties resulted in greater economic federalism and states had the opportunity to influence both the geographical location and the subsequent performance of industrial units by way of differences in the nature of implementation of regulations and the quality of governance, in general, across states. Earlier, location of industrial units was not based on optimal decisions on the part of the firms.

\footnotetext{
${ }^{10}$ In January of 1982, India witnessed the initiation of a massive industrial action in the textile industry. This industrial action continued for 18 months, and spilled over into other industries. It came to an end after the central government took over the management of 13 textile units in October 1983. The long strike in India's (then) largest industry created a severe disruption in investment and the 1982-83 net entry rate was a staggering negative 11 per cent (Figure 1), the lowest for any year since 1975-76. During the eighties, 1986-87 was the only other year where the net entry rate was negative (minus 3 per cent).
} 
But, in the nineties, industrial units were increasingly located in states that were industry friendly and had a better investment climate (Figure 2) ${ }^{11}$ It is immediately evident that in most states the net entry rate in the nineties has been considerably higher than in the eighties, and that a drop in average entry rates are concentrated among four states: Uttar Pradesh, Madhya Pradesh, Andhra Pradesh and Bihar. With the exception of Andhra Pradesh, all these states are known for their poor governance levels, and low levels of economic prosperity. In other words, there is prima facie evidence to suggest that, in keeping with our empirical specification, statelevel factors may indeed have affected inter-industry and inter-state variations in entry rates during the post-1991 period in India.

\section{Entry: regression results}

Following Klapper et al. (2006), we estimate equation (2) using OLS with robust standard errors. The regression estimates for the 1984-91 and 1992-97 periods are reported in Tables 1 and 2, respectively. Starting with roughly the Tybout (1997) specification in column 1, we introduce in column 2 controls for unobserved 2-digit industry level factors that might affect entry rates. In column 3 , we add to the specification the human development index that subsumes state level measures of both growth and development, and hence all the measures of resource endowments, institutions and governance. In a sense, the introduction of the index into the specification is similar to controlling for state level factors using dummy variables. In addition, we control for the proportion of years during each period in which a regional party was in power at the state, and the number of man-days lost on account of industrial strife, per industrial laborer. In column 4, we use the alternative measure of accountability, namely, T\&D loss, instead of the human development index. Following Bhaumik and Estrin (2007), in column 5 , we unpack these measures of accountability and, mindful of the collinearity among state level factors that might affect entry rates, we introduce instead variables that proxy the possible determinants of entry, as discussed earlier in this paper. The F-statistics suggest that our specifications are statistically meaningful, and the coefficient estimates are largely robust across the specifications.

INSERT Tables 1 and 2 about here.

The coefficient estimates reported in Table 1 indicate that, during the 1984-91 period, entry was driven very significantly by industry level growth, and unobserved industry-level factors. The state level factors played a relatively small role in explaining entry, and, as highlighted by the counterintuitive positive sign of the industrial strife variable, the state level

${ }^{11}$ The states considered here account for more than 95 per cent of all industrial units and the total population. 
variables do not necessarily provide an adequate explanation of the pattern of entry across industries and states.

The results reported in Table 2 suggest that industry level growth continued to have a positive impact on entry during the $1992-97$ period. However, entrepreneurs were clearly thinking more strategically in the post-1991 period of competition than in the pre-1991 period that was arguably pro-incumbent (Rodrik and Subramanian, 2004). This is evident from the negative impact of industry concentration on entry, one that was not observed during the 198491 period. To recapitulate, firms belonging to concentrated industries adopt various strategies to reduce the likelihood of entry, including influencing the creation and enforcement of government regulations in a way that raises the entry barriers facing potential entrants (Chari and Gupta, 2005).

At the same time, state level factors played a significantly greater part in the post-1991 period than in the pre-1991 period, a result that is consistent with the conclusions drawn by Kochhar et al. (2006) and Aghion et al. (2005). To begin with, net entry was positively correlated with state-level human development index, and negatively correlated with T\&D losses. This indicates that net entry is during the 1990s was higher in states where governments were reforms minded, and thereby mindful of T\&D losses, and, at the same time, adopted policies that enhanced the human capital of the residents of those states. The more detailed analysis reported in column 5 of the table suggests that entry during the 1992-97 period was significantly influenced by the state level literacy rates, a proxy for educational attainments of the state residents. This is consistent with the stylized fact that India's industrialization during the post-1991 period has been driven significantly by industries like pharmaceuticals and auto ancillaries that require skilled labor, rather than by low skilled mass manufacturing industries. Not surprisingly, states with high levels of industrialization, as captured by the contribution of the manufacturing to state GDP, attracted more firms than states where the initial level of industrialization was low. ${ }^{12}$

Surprisingly, however, our measure of a state-level democracy, namely, per capita expenditure on health, had a negative impact on entry. As such, this is inconsistent with the findings of Djankov et al. (2002). But, at a closer look, the difference between our result and those of Djankov et al. lies in the fact that "democracy" for us implies accountability of the government to the all the stakeholders, while to Djankov et al. it was a measure of the ability of the incumbent firms to influence the government to erect regulatory and procedural barriers to entry. The continued electoral success of the communist parties in states like Kerala and West Bengal, where the governments have traditionally been pro-rural development, and the recent electoral loss of the Telegu Desam Party in Andhra Pradesh, the emerging hub of high

${ }^{12}$ For example, the average entry rate increased substantially for Maharashtra (from 0.56 to 2.31 ) and Gujarat (from 0.40 to 2.35), two states that were highly industrialized prior to 1991 . 
technology industry, suggests that political accountability in a functioning democracy with a large poverty ridden population may not be consistent with phenomena like entry that are desirable from the point of view of market development. Indeed, if rapid industrial growth in a largely agrarian society increases overall income inequality among the voting population, the stability of the political regime is threatened (Muller, 1988), thereby bringing to a stop economic reforms that might be beneficial for industrial growth but ones that adversely affect the income distribution.

In order to further explore the growing importance state level factors in determining patterns of entry and, therefore, industrialization, in post-1991 India, we undertook the following exercise: We regressed the change in the number of plants during the 1984-91 and 1992-97 periods, our dependent variables for the estimates reported in Tables 1 and 2, on the initial number of plants for each industry in each state, and on 3-digit industry dummy variables and state dummy variables. For the 1984-91 period, the adjusted R-square value for the resultant regression model was 0.19 , comparable with the adjusted R-square values reported in Table 1. For the 1992-97 period, however, the adjusted R-square value yielded by this exercise was 0.14, much higher than the adjusted R-square values of (about) 0.05 reported in Table 2 . Experimentation with the specification suggested that much of this additional predictive power is on account of the state dummy variables. While adjusted R-square models are not strictly comparable across non-nested regression models with different sample size, this provides with a reasonably strong evidence that unobserved state level factors that we have not accounted for in our regression models had a strong influence on entry during the post-1991 era of economic federalism. The plausible classification of these unobserved factors can be made under the header "institutions and governance."

Finally, we undertook two different robustness checks. First, we took into account the possibility that while state-level factors reflect long-term steady states that are not significantly affected by policy changes and entry and exit of firms in the short run, the industry level variables are not immune to entry and policy changes, and that, therefore, using period averages of industry level variables on the right hand side of equation [2] might give rise to endogeneity. Hence, we re-estimated the models using the initial (i.e., 1984 and 1992 for Tables 2 and 3, respectively) values of the industry level variables, instead of using their period averages. Second, we took into consideration that possibility that the impact of industry level and state level variables on net entry may be different for high technology and low technology industries. $\mathrm{We}$, therefore, re-estimated our regression models separately for low technology and mediumto-high technology industries, using the classification for technological intensity of the OECD. The new coefficient estimates, which are not reported in the paper, indicate that our results are robust to these exercises. 


\section{Entry and productivity}

While the main purpose of this paper is to examine the relative importance of industry-specific and institutional factors in determining entry rates in two different economic regimes in India, in for the sake of completeness, in this section we extend the analysis to an examination of the relationship between entry and productivity growth as well. We first estimate productivity growth in the 3-digit industries using the following growth accounting equation: ${ }^{13}$

$$
\frac{\Delta A}{A_{t}}=\frac{\Delta Y}{Y_{t}}-\alpha \frac{\Delta K}{K_{t}}-(1-\alpha) \frac{\Delta L}{L_{t}}
$$

when $\Delta A / A_{t}$ is the growth rate of productivity, $\Delta Y / Y_{t}$ is the growth rate of value added, $\Delta K / K_{t}$ is the growth rate of capital stock, $\Delta L / L_{t}$ is the growth rate of labour, $\alpha$ is the average of ratio of labour cost to value added in periods $t$ and $t-1$, and $(1-\alpha)$ is the average of ratio of labour cost to value added in periods $t$ and $t-1 .{ }^{14}$ In keeping with our earlier analysis, which examined entry rates over a number of years, rather than examine year-on-year changes, we estimate productivity growth between 1984 and 1991, and that between 1992 and 1997. The decision to estimate productivity growth rates for a group of years as opposed to every single year is the same as before, namely, that any relationship between entry and productivity is likely to observed in the medium to long run. The estimates of productivity growth indicate that during the 1984-91 and 1992-97 periods the growth rate of positive in 24.8 percent and 34.31 percent of the industries. ${ }^{15}$

INSERT Table 3 about here.

Next, we examine the likely impact of entry on productivity. This impact, if any, is likely to be contemporaneous; in principle, productivity growth is affected as firms with higher than average productivity enter a market and/or firms with lower than average productivity leave the market. For each period, the correlation between net entry rates and productivity growth rates is less than 0.05 , indicating that the contemporaneous relationship between entry and productivity growth was weak, if any, in both time periods. For each of these periods, we also regress the binary indicator of positive productivity growth on the net entry rate for that

\footnotetext{
${ }^{13}$ We thank an anonymous referee for suggesting this method for computing productivity growth.

${ }^{14}$ Note that the implicit assumption of constant returns to scale technology in Indian industries during the 1980s and the 1990s is consistent with the available evidence (Bhaumik and Kumbhakar, 2007).

${ }^{15}$ Over the two time periods, there was a fair degree of mobility across the categories as well. A third of the industries that had experienced zero or negative productivity growth during the 1980s experienced positive productivity growth during the 1990s. Similarly, 38 percent of the industries that had experienced positive productivity growth during the 1980s witnessed zero or negative productivity growth during the 1990s.
} 
period, with and without controls for 2-digit industries. The results of the probit models, not reported in the paper, indicate that net entry rates did not significantly affect productivity growth in either period. This result is consistent with that of Bhaumik and Kumbhakar (2007) who find that average plant-level technical efficiency declined in India's manufacturing industries despite liberalisation, possibly on account of factors such as barriers to exit of inefficient and less productive firms, and family-oriented ownership structures that have a detrimental effect on management quality of the firms.

Finally, we estimate the impact of productivity on entry. Note that while entry might have an immediate impact on productivity if, for example, the entering firms have different levels of productivity than the incumbent firms, there is no reason to believe that any change in industry-level productivity would have a contemporaneous impact on entry rates. ${ }^{16}$ A change in the industry-level productivity is likely to impact net entry rates by affecting over time the cost levels that would, in turn, affect growth rate of the value added. In order to examine this relationship further, for 1992-97, we re-estimate equation (2) with an additional explanatory variable, namely, a binary indicator of productivity growth during the 1984-91 period; the binary indicator takes the value unity if productivity growth is positive. The rest of the variables in the specification are similar to that of model (5) in Table 2. The regression results are reported in Table 3. It can be seen that productivity growth does indeed have an impact on entry rate, and, in keeping with our prior, the coefficient of the growth rate of value added loses its significance. The signs and significance of rest of the estimates are unaffected.

\section{Concluding remarks}

In this paper, we make an important contribution to the literature on entry. We demonstrate that in a liberalised economic environment where there is spatial heterogeneity in governance quality, entry rates are likely to be influenced much more by such location-specific institutional factors than by stylised industry-level factors such as growth and market structure. In the Indian context, while net entry during the 1980s was affected mostly by observed and unobserved industry-level factors, during the 1990s, which was marked by greater economic federalism, variations in net entry rate are much more closely correlated to state-level factors. Further, we identify observable location-specific factors that might affect entry rates. An interesting finding is that in a society where there are multiple stakeholders, an increase in the extent of democratisation might actually affect entry rates adversely, presumably on account of

\footnotetext{
${ }^{16}$ Indeed, if productivity growth had a contemporaneous impact on entry rates as well, the appropriate empirical model would have involved a simultaneous equation system, with entry rates and productivity growth as the two endogenous variables. However, as explained earlier in this paper, in the stylised literature (Tybout, 1997; Perotti and Volpin, 2004; Klapper et al., 2006), it is customary to examine entry rates within single equation frameworks in which these rates depend on industry-level factors other than productivity growth, and institutional variables.
} 
coordination problem involving the stakeholders who benefit from entry and industrialisation to different extent. This brings into focus the need to widen the discussion about market entry in developing countries from the relative powers of incumbent firms and potential entrants in influencing regulatory and procedural barriers to one involving all the stakeholders, some of whom do not participate in, nor benefit from, the process of industrialisation. 


\section{References}

Aghion, Philippe and Patrick Bolton, 1987. Contracts as a barrier to entry. American Economic Review 77, 388-401.

Aghion, Philippe Robin Burgess, Stephen J. Redding and Fabrizio Zilibotti, 2008. The unequal effects of trade liberalization: Dismantling the licence raj in India. American Economic Review, 94:4, 1397-1412.

Aghion, Philippe et al., 2005. Entry liberalisation and inequality in industrial performance. Journal of European Economic Association, 3:2-3, 291-302.

Aw, Bee Y., Xiaomin Chen and Mark J. Roberts, 2001. Firm level evidence on productivity differentials and turnover in Taiwanese manufacturing. Journal of Development Economics 66:1, 51-86.

Bain, Joseph S., 1956. Barriers to new competition, Cambridge, MA: Harvard University Press.

Baldwin, John R. and Paul K. Gorecki, 1991. Entry, exit and productivity growth. In: Paul Geroski and Joachim Schwalback Eds., Entry and market contestability: An international comparison. Oxford: Blackwell.

Barro, Robert J., 1991. Economic growth in a cross section of countries. Quarterly Journal of Economics 107, 407-443.

Bartelsman, Eric, John Haltiwanger and Stefano Scarpetta, 2004. Microeconomic evidence of creative destruction in industrial and developing countries. Discussion paper no. 1374, IZA-Institute for the Study of Labour, Bonn.

Besley, Timothy and Robin Burgess, 2004. Can labor regulation hinder economic performance? Evidence from India. Quarterly Journal of Economics 119:1, 91-134.

Bhagwati, Jagdish N. and Padma Desai, 1970. Planning for industrialization. London: Oxford University Press.

Bhaumik, Sumon K. and Saul Estrin, 2007. How transition paths differ: Enterprise performance in Russia and China. Journal of Development Economics, 82:2, 374-392.

Bhaumik, Sumon K. and Subal C. Kumbhakar, 2007. Impact of regulatory and institutional changes with plant-level productivity and technical efficiency. Discussion paper no. 3347, IZA - Institute for the Study of Labor, Bonn.

Bhaumik, Sumon K., Shubhashis Gangopadhyay and Shagun Krishnan, 2008. Policy, economic federalism, and product market entry: The Indian experience. European Journal of Development Research, 20:1, 1-30.

Bolton, Patrick and Michael D. Whinston, 1991. The foreclosure effects of vertical mergers. Journal of Institutional and Theoretical Economics 147, 207-226.

Bolton, Patrick and Michael D. Whinston, 1993. Incomplete contracts, vertical integration, and supply constraints. Review of Economic Studies 60, 121-148.

Botero, Juan Carlos et al., 2003. The regulation of labor. Quarterly Journal of Economics 119:4, 1339-1382.

Chari, Anusha and Nandini Gupta, 2005. The political economy of foreign entry liberalization. Mimeo, University of Michigan, Ann Arbor, http://webuser.bus.umich.edu/achari/webpage michigan/polecon_chari gupta.pdf.

Chirinko, Robert S. and Julie Ann Elston, 2006. Finance, control and profitability: The influence of German banks. Journal of Economic Behavior and Organization 59:1, 6988.

De Soto, Hernando, 1989. The other path. New York: Harpers and Row.

Dixit, Avinash, 1980. The role of investment in entry deterrence. Economic Journal 90, 95-106.

Djankov, Simeon, Rafael La Porta, Florencio Lopez-de-Silanes and Andrei Shleifer, 2002. The regulation of entry. Quarterly Journal of Economics 117, 1-35.

Eaton, B. Curtis and Richard G. Lipsey, 1980. Exit barriers are entry barriers: The durability of capital as a barrier to entry. Bell Journal of Economics 11:2, 721-729.

Evans, David S. and Boyan Jovanovic, 1989. An estimated model of entrepreneurial choice under liquidity constraints. Journal of Political Economy 97:4, 808-827.

Geroski, Paul, 1995. What do we know about entry? International Journal of Industrial Organization 13, 421-440. 
Geroski, Paul and Andy Murfin, 1998. Entry and industry evolution: The UK car industry, 1958-83. Applied Economics 23, 799-810.

Hart, Oliver and Jean Tirole, 1990. Vertical integration and market foreclosure. Brookings Paper on Economic Activity: Microeconomics.

Hasan, Rana, Devashish Mitra and K.V. Ramaswamy, 2003. Trade reforms, labor regulations and labor demand elasticities: Empirical evidence from India. Working paper no. 9879, National Bureau of Economic Research, Cambridge, Massachusetts.

Hoover, Edgar M. 1948. The location of economic activity. New York: McGraw-Hill.

Jovanovic, Boyan and Saul Lach, 1989. Entry, exit and diffusion with learning by doing. American Economic Review 79:4, 690-699.

Joshi, Vijay and I.M.D. Little, 1994. India: Macroeconomics and political economy, 1964-1991. New York: Oxford University Press.

Klapper, Leora, Luc Laeven and Raghuram Rajan, 2006. Entry regulation as a barrier to entrepreneurship. Journal of Financial Economics, 82:3, 591-629.

Kochhar, Kalpana et al., 2006. India's pattern of development: What happened, what follows. Journal of Monetary Economics, 53:5, 981-1019.

Krugman, Paul, 1991. Increasing returns and economic geography. Journal of Political Economy 99:3, 483-499.

Lall, Somik V. and Sanjoy Chakravorty, 2005. Industrial location and spatial inequality: Theory and evidence from India. Review of Development Economics 9:1, 47-68.

Liu, Lili, 1993. Entry-exit, learning, and productivity change: Evidence from Chile. Journal of Development Economics 42, 217-242.

Muller, Edward N., 1988. Democracy, economic development, and income inequality. American Sociological Review 53, 50-68.

Nickell, Stephen J., 1996. Competition and corporate performance. Journal of Political Economy 104:4, 724-746.

Perotti, Enrico and Paolo Volpin, 2004. Lobbying for entry. Discussion paper no. 2004-088/2, Tinbergen Institute, Amsterdam, The Netherlands.

Pesaran, M. Hashem and Ronald P. Smith, Ron, 1995. Estimating long-run relationships from dynamic heterogeneous panels. Journal of Econometrics, 68:1, 79-113,

Pilat, Dirk, 1996. Competition, productivity and efficiency. OECD Economic Studies No. 27.

Pourgerami, Abbas, 1988. The political economy of development: A cross-national causality test of development-democracy-growth hypotheses. Public Choice 58, 123-141.

Rasmusen, Eric, J. Mark Ramseyer and J. Shepard Wiley, 1991. Naked exclusion. American Economic Review 81, 1137-1145.

Rodrik, Dani and Arvind Subramanian, 2004. From "Hindu growth" to productivity surge: The mystery of the Indian growth transition. IMF Staff Papers 52:2, 193-228.

Schmalensee, Richard, 1978. Entry deterrence in the ready to eat cereals industry. Bell Journal of Economics 9, 305-327.

Seabright, Paul, 1996. The starfish effect: Can market entry by one firm encourage further entry by others? European Economic Review 40, 541-550.

Stasavage, David, 2005. Democracy and education spending in Africa. American Journal of Political Science 49, 343-358.

Stennek, Johan, 2000. Competition increases x-efficiency: A limited liability mechanism. European Economic Review 44, 1727-1744.

Stigler, George, 1968. The organization of industry. Chicago, IL: University of Chicago Press.

Tybout, Roberts J., 1997. Chile, 1979-86: Trade liberalization and its aftermath. In: Roberts, Mark J. and James R. Tybout Eds., Industrial evolution in developing countries: Micro patterns of turnover, productivity and market structures. New York: Oxford University Press.

Virmani, Arvind, 2004. Economic reforms: Policy and institutions, some lessons from the Indian experience. Working paper no. 121, Indian Council for Research on International Economic Relations, New Delhi. 
Figure 1

Variations in net entry rates over time

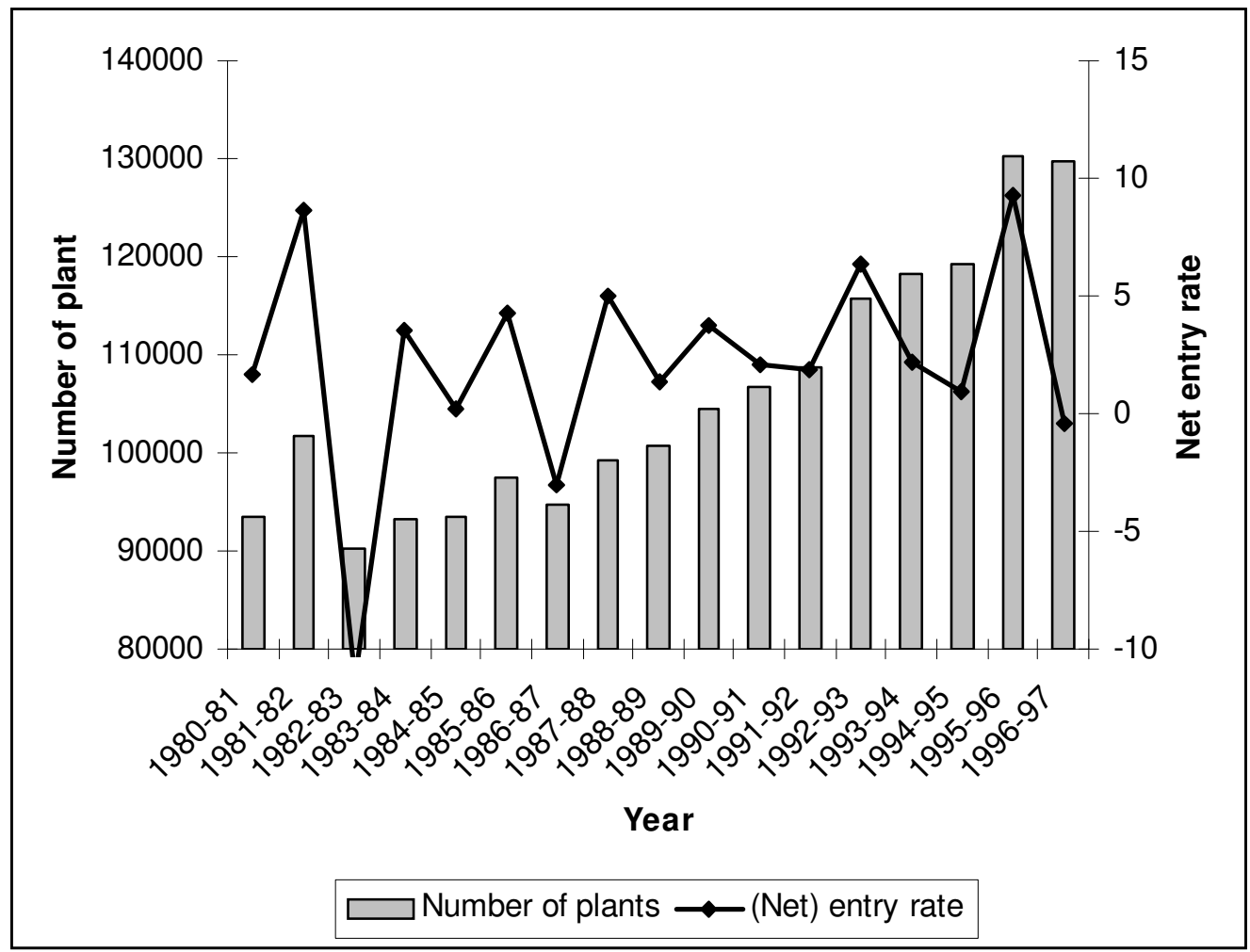




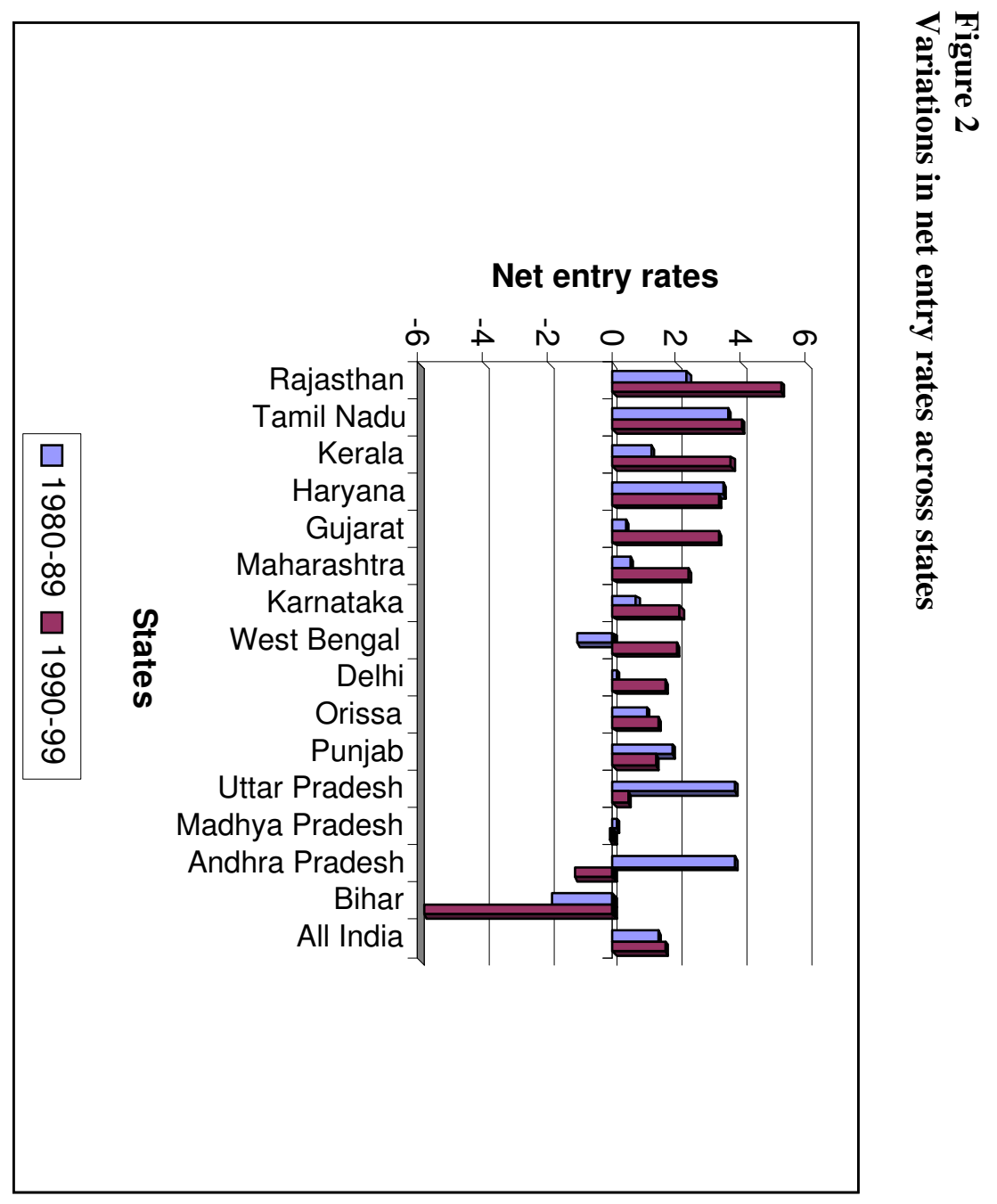


Table 1

Determinants of net entry (1984-91)

\begin{tabular}{|c|c|c|c|c|c|}
\hline & (1) & (2) & (3) & (4) & (5) \\
\hline Constant & $\begin{array}{l}-28.72 * * \\
(14.33)\end{array}$ & $\begin{array}{l}-28.32 * * \\
(14.55)\end{array}$ & $\begin{array}{r}-38.47 * \\
(21.82)\end{array}$ & $\begin{array}{r}-51.33 * \\
(28.66) \\
\end{array}$ & $\begin{array}{c}-76.11 \\
(48.67)\end{array}$ \\
\hline Initial number of plants & $\begin{array}{l}0.34 \\
(0.24)\end{array}$ & $\begin{array}{l}0.34 \\
(0.24)\end{array}$ & $\begin{array}{l}0.35 \\
(0.24)\end{array}$ & $\begin{array}{l}0.34 \\
(0.24)\end{array}$ & $\begin{array}{l}0.35 \\
(0.25)\end{array}$ \\
\hline Growth of value added & $\begin{array}{l}3.54 * * \\
(1.45)\end{array}$ & $\begin{array}{l}3.15 * * \\
(1.63)\end{array}$ & $\begin{array}{l}3.37 * * \\
(1.76)\end{array}$ & $\begin{array}{l}3.15 * * \\
(1.63)\end{array}$ & $\begin{array}{l}3.37 * * \\
(1.76)\end{array}$ \\
\hline Capital-to-labour ratio & $\begin{array}{l}2.49 \\
(2.79)\end{array}$ & $\begin{array}{l}1.77 \\
(3.10)\end{array}$ & $\begin{array}{l}1.95 \\
(3.24)\end{array}$ & $\begin{array}{l}1.77 \\
(3.07)\end{array}$ & $\begin{array}{l}2.01 \\
(3.20)\end{array}$ \\
\hline 4-plant concentration ratio & $\begin{array}{l}0.08 \\
(0.23)\end{array}$ & $\begin{array}{l}0.12 \\
(0.23)\end{array}$ & $\begin{array}{l}0.13 \\
(0.25)\end{array}$ & $\begin{array}{l}0.12 \\
(0.24)\end{array}$ & $\begin{array}{l}0.13 \\
(0.25)\end{array}$ \\
\hline Industry controls & No & Yes $* * *$ & Yes $* * *$ & Yes $* * *$ & Yes $* * *$ \\
\hline Human development index & & & $\begin{array}{l}-18.91 \\
(23.01)\end{array}$ & & \\
\hline $\mathrm{T} \& \mathrm{D}$ loss & & & & $\begin{array}{l}0.53 \\
(0.90)\end{array}$ & \\
\hline $\begin{array}{l}\text { Man days lost because of } \\
\text { industrial action (per } \\
\text { worker) }\end{array}$ & & & $\begin{array}{l}58.84 * \\
(35.91)\end{array}$ & $\begin{array}{l}55.98 * \\
(33.71)\end{array}$ & $\begin{array}{l}59.37 * \\
(34.43)\end{array}$ \\
\hline Literacy rate (percentage) & & & & & $\begin{array}{c}-0.09 \\
(0.14)\end{array}$ \\
\hline $\begin{array}{l}\text { Per capita total expenditure } \\
\text { on health }\end{array}$ & & & & & $\begin{array}{c}-0.09 \\
(0.14)\end{array}$ \\
\hline $\begin{array}{l}\text { Manufacturing as } \\
\text { percentage of state GDP }\end{array}$ & & & & & $\begin{array}{l}53.58 \\
(44.71)\end{array}$ \\
\hline Growth of state GDP & & & & & $\begin{array}{l}3.43 \\
(2.84)\end{array}$ \\
\hline $\begin{array}{l}\text { Proportion of years } \\
\text { governed by regional party }\end{array}$ & & & $\begin{array}{l}6.04 \\
(4.46)\end{array}$ & $\begin{array}{l}4.78 \\
(5.77)\end{array}$ & $\begin{array}{l}-1.96 \\
(10.90)\end{array}$ \\
\hline $\begin{array}{l}\text { F-statistics } \\
\text { Prob }>\text { F-statistics }\end{array}$ & $\begin{array}{l}8.91 \\
(0.00)\end{array}$ & $\begin{array}{l}5.42 \\
(0.00)\end{array}$ & $\begin{array}{l}4.40 \\
(0.00)\end{array}$ & $\begin{array}{l}4.60 \\
(0.00)\end{array}$ & $\begin{array}{l}3.75 \\
(0.00)\end{array}$ \\
\hline Adjusted R-square & 0.191 & 0.187 & 0.195 & 0.194 & 0.196 \\
\hline Nobs & 1650 & 1650 & 1540 & 1650 & 1540 \\
\hline
\end{tabular}

Note: The values within parentheses are robust standard errors. $* * *, * *$ and $*$ indicate significance at $1 \%, 5 \%$ and $10 \%$ levels, respectively. 
Table 2

Determinants of net entry (1992-97)

\begin{tabular}{|c|c|c|c|c|c|}
\hline & (1) & $(2)$ & (3) & (4) & (5) \\
\hline Constant & $\begin{aligned}-2.77 \\
(11.41)\end{aligned}$ & $\begin{array}{l}-1.37 \\
(13.13)\end{array}$ & $\begin{array}{c}-16.94 \\
(16.98)\end{array}$ & $\begin{array}{l}3.78 \\
(16.02)\end{array}$ & $\begin{array}{r}-25.89 * \\
(15.28)\end{array}$ \\
\hline Initial number of plants & $\begin{array}{l}0.04 \\
(0.07) \\
\end{array}$ & $\begin{array}{l}0.04 \\
(0.07) \\
\end{array}$ & $\begin{array}{l}0.04 \\
(0.07) \\
\end{array}$ & $\begin{array}{l}0.04 \\
(0.43\end{array}$ & $\begin{array}{l}0.04 \\
(0.07)\end{array}$ \\
\hline Growth of value added & $\begin{array}{l}0.74 * * \\
(0.36)\end{array}$ & $\begin{array}{l}1.03 * * \\
(0.44)\end{array}$ & $\begin{array}{l}1.02 * * \\
(0.46)\end{array}$ & $\begin{array}{l}1.03 * * \\
(0.43)\end{array}$ & $\begin{array}{l}1.03 * * \\
(0.44)\end{array}$ \\
\hline Capital-to-labour ratio & $\begin{array}{l}3.84 * \\
(2.12)\end{array}$ & $\begin{array}{l}3.44 \\
(2.57)\end{array}$ & $\begin{array}{l}3.66 \\
(2.74)\end{array}$ & $\begin{array}{l}3.43 \\
(2.57)\end{array}$ & $\begin{array}{l}3.41 \\
(2.56)\end{array}$ \\
\hline 4-plant concentration ratio & $\begin{array}{c}-0.19 * * \\
(0.09)\end{array}$ & $\begin{array}{l}-0.27 * * * \\
(0.10)\end{array}$ & $\begin{array}{l}-0.28 * * * \\
(0.11)\end{array}$ & $\begin{array}{l}-0.27 * * * \\
(0.10)\end{array}$ & $\begin{array}{l}-0.27 * * * \\
(0.10)\end{array}$ \\
\hline Industry controls & No & Yes * & Yes * & Yes $*$ & Yes * \\
\hline Human development index & & & $\begin{array}{l}33.76 * \\
(18.99)\end{array}$ & & \\
\hline T\&D loss & & & & $\begin{array}{c}-0.31 * \\
(0.18)\end{array}$ & \\
\hline $\begin{array}{l}\text { Man days lost because of } \\
\text { industrial action (per } \\
\text { worker) }\end{array}$ & & & $\begin{array}{l}11.61 \\
(33.20)\end{array}$ & $\begin{array}{l}23.99 \\
(29.95)\end{array}$ & $\begin{array}{l}3.61 \\
(34.43)\end{array}$ \\
\hline Literacy rate (percentage) & & & & & $\begin{array}{l}0.43 * * \\
(0.17)\end{array}$ \\
\hline $\begin{array}{l}\text { Per capita total expenditure } \\
\text { on health }\end{array}$ & & & & & $\begin{array}{l}-19.53 * * \\
(8.27)\end{array}$ \\
\hline $\begin{array}{l}\text { Manufacturing as } \\
\text { percentage of state GDP }\end{array}$ & & & & & $\begin{array}{l}48.23 * * \\
(18.82)\end{array}$ \\
\hline Growth of state GDP & & & & & $\begin{array}{l}0.13 \\
(0.18)\end{array}$ \\
\hline $\begin{array}{l}\text { Proportion of years } \\
\text { governed by regional party }\end{array}$ & & & $\begin{array}{l}-1.93 \\
(5.29) \\
\end{array}$ & $\begin{array}{l}-1.86 \\
(5.21)\end{array}$ & $\begin{array}{l}-3.62 \\
(5.62)\end{array}$ \\
\hline $\begin{array}{l}\text { F-statistics } \\
\text { Prob }>\text { F-statistics }\end{array}$ & $\begin{array}{l}5.67 \\
(0.00)\end{array}$ & $\begin{array}{l}2.41 \\
(0.00)\end{array}$ & $\begin{array}{l}2.73 \\
(0.00)\end{array}$ & $\begin{array}{l}2.55 \\
(0.00)\end{array}$ & $\begin{array}{l}2.75 \\
(0.00)\end{array}$ \\
\hline Adjusted R-square & 0.032 & 0.037 & 0.039 & 0.037 & 0.041 \\
\hline Nobs & 1560 & 1560 & 1456 & 1560 & 1560 \\
\hline
\end{tabular}

Note: The values within parentheses are robust standard errors. $* * *, * *$ and $*$ indicate significance at $1 \%, 5 \%$ and $10 \%$ levels, respectively. 
Table 3

Impact of productivity on net entry (1992-97)

\begin{tabular}{|c|c|}
\hline Constant & $\begin{array}{r}-26.44 * \\
(15.28) \\
\end{array}$ \\
\hline Initial number of plants & $\begin{array}{l}0.03 \\
(0.07)\end{array}$ \\
\hline Growth of value added & $\begin{array}{l}0.26 \\
(0.52)\end{array}$ \\
\hline Capital-to-labour ratio & $\begin{array}{l}4.16 \\
(2.73)\end{array}$ \\
\hline 4-plant concentration ratio & $\begin{array}{c}-0.30 * * * \\
(0.11)\end{array}$ \\
\hline Productivity growth during 1984-91 & $\begin{array}{l}11.50 * * \\
(5.04)\end{array}$ \\
\hline Industry controls & Yes * \\
\hline Man days lost because of industrial action (per worker) & $\begin{array}{l}3.58 \\
(34.20)\end{array}$ \\
\hline Literacy rate (percentage) & $\begin{array}{l}0.43 * * \\
(0.17)\end{array}$ \\
\hline Per capita total expenditure on health & $\begin{array}{l}-19.50 * * \\
(8.24)\end{array}$ \\
\hline Manufacturing as percentage of state GDP & $\begin{array}{l}48.16 * * \\
(18.89) \\
\end{array}$ \\
\hline Growth of state GDP & $\begin{array}{l}0.12 \\
(0.17)\end{array}$ \\
\hline Proportion of years governed by regional party & $\begin{array}{l}-3.66 \\
(5.60)\end{array}$ \\
\hline $\begin{array}{l}\text { F-statistics } \\
\text { Prob }>\text { F-statistics }\end{array}$ & $\begin{array}{l}2.78 \\
(0.00)\end{array}$ \\
\hline Adjusted R-square & 0.048 \\
\hline Nobs & 1560 \\
\hline
\end{tabular}

Note: The values within parentheses are robust standard errors. $* * *, * *$ and $*$ indicate significance at $1 \%, 5 \%$ and $10 \%$ levels, respectively. 


\section{APPENDIX}

Let the following be true:

$B_{t}=$ number of large firms in period $t$ that are included in the census sector of ASI data

$S_{t}=\quad$ number of small and medium firms in period $t$ that are included in the sample sector of ASI data

$a=$ number of new large firms entering the product market

$b=$ number of incumbent large firms exiting the product market

$c=$ number of small and medium firms growing in size and becoming part of the census sector

$d=$ number of large firms that reduce in size and become part of the sample sector

$e \quad=\quad$ number of new small and medium firms entering the product market

$f=$ number of incumbent small and medium firms exiting the product market

Suppose that all large firms are captured in a survey, while only one in three small and medium firms are reported. In other words, data reported for two successive surveys provide us with the following information:

$$
A \equiv\left(B_{t+1}-B_{t}\right)+\frac{1}{3}\left(S_{t+1}-S_{t}\right)=(a-b)+\frac{1}{3}(e-f)+\frac{2}{3}(c-d)
$$

It is easily seen that, in the absence of the possibility to move from the census sector to the sample sector, and vice versa, the following is true:

$$
B \equiv\left(B_{t+1}-B_{t}\right)+\left(S_{t+1}-S_{t}\right)=(a-b)+\frac{1}{3}(e-f)
$$

which is a monotonic transformation of the actual net entry that is given by $\{(a-b)+(e-f)\}$.

It is also easily seen that $A$ would be a monotonic transformation of $B$, and therefore of the actual net entry, if the following were true: $c>d$. Since small and medium firms are much more likely to grow into larger firms, while poorly performing larger firms are more likely to exit than to exist with a much diminished presence, and given that there are many more small and medium firms relative to large firms, it would be reasonable to assume that indeed $c>d$.

Hence, our measure of net entry, which is captured by $A$, is a monotonic transformation of the actual measure of net entry. 